\title{
乳癌及び子宮癌の放射性同位元素 $\left(\mathrm{P}^{32}\right)$ に上る診断法
}

\author{
田淵 昭 中田義正 中村勝彦
}

（㣖岛医科大学産媂人科学教宔）

Low-Beer は 1942 年初めて皮膚癌, ホドキン 氏病等の疾患につき $\mathrm{P}^{32}$ 静注による診断法を発表 し, その後更に乳癌の患者につんて詳細な研究を 行い，之がリンパ腺転移の存在並に範囲の検索を も可能なるととを報じている。即ち彼てよると， $\mathrm{P}^{32}$ 追䟢子量を 300 乃至 $500 \mu \mathrm{c}$ として静注し,ガ イガー計数管によりカウント数を測定すると癌巣 では 25 乃至 150\%の堌加が認められると云っ て居る。

その後 Cramer-Pabst 等は 300 例の各種腫瘍 に就て同様 $\mathrm{P}^{32}$ 亿依る診断法を用ん, この診断法 は臨床的に意義があると述へでり，本邦に於て 8森氏（1954）は子宮癌殊に早期癌に応用し, 好 成績を得をと報じているが，吾くは主て乳癌及び 子宮癌の診断に $\mathrm{P}^{32}$ を応用し, 研究を続けている。 此処には今日迄の知見の要点を中間報告する。

\section{実験材料及び方法：}

子宮癌患者は教室の入院患者を利用し, 乳癌患 者は本学上村外科教室の御援助を得, 且之が対照 は教室の入院患者に就て検索を実施した。
$\mathrm{P}^{32}$ は放射性第二燐酸ソーダ溶液 ( $\mathrm{pH} \mathrm{72)} 2$ し, 之を $20 \%$ 葡萄糖溶液に加へて肘静脉から注 入し，(追跡子量は 4 乃至 $8 \mu \mathrm{c} / \mathrm{kg}$ とした。）測 定器は神戸工業製 SC-100 A 型計数器を使用し, 注射后 30 分 $1,2,4,6,8,12,24,48,72$ 時間 て夫ネカンウト (c. p. m.) を測定した。

\section{乳秥の診断成績}

使用した G-M 管は神戸工業製 G-M 131 型 で, 皮虞面より $0.5 \mathrm{~cm}$ 亿於て乳癌患者の癌部之 他側の対照とを比較すると, c. p. m. は第 1 例で は静注后 30 分では $4.2: 2.2,1$ 時間では $4.1: 1.9$ 2 時間では $3.9: 1,4$ 時間では $4.0: 1.5,6$ 時間 では $4.1: 1.3,8$ 時間では $3.9: 1.2,12$ 時間で は $3.0: 1.2,24$ 時間では $28: 1.0$ 示し, 注射 1 時間后よりの c. p. m. の比は時間の 経過に 関らす略一定であった。以下第 2 例, 第 3 例, 第 4 例の癌部 c. p. m. 増加率の時間的経過第 1 表の如く, 明らかに癌部は対照である健側に比し 増加を示してんる。然ると Mastopathia cystica の 1 例之子宮癌患者の 2 例では，（第 5 例, 第 6 例

\begin{tabular}{|c|c|c|c|c|c|c|c|c|c|c|c|c|c|c|}
\hline 莚例番号 & 年令 & 追跡子量 & 30 分后 & 1 時間 & 2 時間 & 4 時間 & 6 時間 & 8 時間 & 12時間 & 24時間 & |48時間| & 72 時間 & \begin{tabular}{|l} 
診断 \\
筀
\end{tabular} & |組織邶断 \\
\hline 1 & 42 & $8 \mu \mathrm{c} / \mathrm{kg}$ & $90 \%$ & $115 \%$ & $116 \%$ & $166 \%$ & $214 \%$ & $225 \%$ & $150 \%$ & $180 \%$ & & & + & 右乳癌 \\
\hline 2 & 30 & 8 & 45 & 23 & 32 & 40 & 29 & 29 & 36 & 34 & 24 & 76 & + & 右乳稞 \\
\hline 3 & 50 & 8 & 82 & 110 & 81 & 77 & 66 & 87 & 75 & 85 & 97 & & + & 左我葟 \\
\hline 4 & 47 & 8 & 115 & 137 & 129 & 92 & 84 & 88 & 130 & 114 & 108 & & + & 左乳痹 \\
\hline 5 & 31 & 4 & 4 & 0 & 0 & 2 & 6 & 0 & 2 & 4 & 1 & & - & 右乳腺症 \\
\hline 6 & 51 & 4 & 2 & 0 & 2 & 0 & 0 & 1 & 1 & 0 & 0 & 0 & - & 対 照 \\
\hline 7 & 43 & 8 & 2 & 1 & 0 & 0 & 1 & 1 & 2 & 0 & 0 & 1 & - & 対 照 \\
\hline
\end{tabular}


第 7 例の如く）両側乳房の c. p. m. の比は殆ん ご等しかった。

以上の結果より癌性変化を来せる組織部に於け る $\mathrm{P}^{32}$ の㩒取量は明らかて非癌部組織より大で あり，且その比は数倍であるととが窺える。又第 1 例及び第 3 例は注射后 24 及び 48 時間后に手 術を施行し，剔出腫湯のラヂオオートグラフを作 製したが，之による之浸潤の無い上皮下組織及び 筋肉の夫れと比較し，著明な黒化を認めた。佾診 断は何れも病理組織学的検查を参考己した。

\section{子宮癌の診断成績}

使用した G-M 管は神戸工業製 G-M 793 型, 即ち長さ $12 \mathrm{~cm}$, 直経 $2 \mathrm{~mm}$ の注射針型のもの で，とれに附属の増幅装置を捙入し，直接癌部の c. p. m. を測定し, 健康部々思はれる部を対照と した。

症例 1 の実験成績は $\mathrm{P}^{32}$ 静注后 1 時間では癌 部の増加率は非癌部に対して, 3.1:1.2, 4 時間では $2.0: 0.8,24$ 時間では $1.6: 0.5,48$ 時間では 1.76 : 8.0 を示した。c. p. m. は G-M 管の使用時間, 或は保持により不安定のため均一ではなんが, 癌 部の増加率は時間的経過関ら略一定の様に思 はれる。即ち子宮胵部癌 3 例，単純性子宮胵部慗 爛 3 例に就んて実験した結果は第 2 表の如く, 子 宮膛部癌の c. p. m. は非癌部に比較し, 明かに増 加している。然し単純性子宮癌部糜爛では対照部 との比が殆んご等しく，以上の結果より子宮暚に 於ても $\mathrm{P}^{32}$ の癌組織内集積程度は非癌部組織に比 し, 増加してんると考えられ, 組織採取を行う ことなく，G-M 管で直接癌部て集積した $\mathrm{P}^{32} の$ c. p. m. を測定してその診断を得る事が可能乙考 えられる。然し吾々の検索上に於て, 癌の時期的
分類よりすれば，所謂可視癌乃至は偽可視癌の状 態に於て之が臨床的価値はある己思われるが，早 期癌の診断につんては佾今后の研究を要すると考 える。更と本 G-M 管は長時間の使用により，或 ほ之が保持に当り，僅かな振動によっても不安定 そなる事が吕るので，その使用に際しては特に細 心の注意を要する。今后更に改良された G-M 管 の出現が望ましい所以である。

第 2 表 于宾癌の c. p. m. 増加率

\begin{tabular}{|c|c|c|c|c|c|c|c|c|c|}
\hline $\begin{array}{l}\text { 促:例 } \\
\text { 乘号 }\end{array}$ & 年令 & 追跡 & 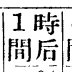 & $\begin{array}{c}4 \text { 時 } \\
\end{array}$ & 閴 & \begin{tabular}{|l}
24 時 \\
間
\end{tabular} & \begin{tabular}{|l|}
48 時 \\
間 \\
\end{tabular} & $\begin{array}{l}\text { 診断 } \\
\text { 判定 }\end{array}$ & 組䋨 \\
\hline 1 & 47 & $8 \mu \mathrm{c} / \mathrm{kg}$ & $\begin{array}{r}\% \\
160 \\
\end{array}$ & $\begin{array}{r}\% \\
150 \\
\end{array}$ & $\begin{array}{r}\% \\
160 \\
\end{array}$ & $\begin{array}{r}\% \\
220\end{array}$ & $\begin{array}{r}\% \\
120 \\
\end{array}$ & + & 臸部癌 \\
\hline 2 & 51 & 4 & 80 & 60 & 60 & 60 & & + & \\
\hline 3 & 43 & 4 & 140 & 140 & 150 & 130 & & + & 臸部癌 \\
\hline 4 & 38 & 8 & 12 & 0 & 7 & 35 & 16 & - & \\
\hline
\end{tabular}

結論：吾ふは乳癌及び子宮癌の診断て $\mathrm{P}^{32}$ を 用んて c. p. m. の時間的経過を追求したが, 癌部 ほ非癌部に比し明かな増加を示し，注射后 1 時間 及び 24 時間のみを以てしてもその診断価值は臨 床に意義あるもの子考えられ, 且全例飞於て副作 用もなんので，との方法は臨床上実用に供し得る 診断法己考える。

\section{参考交献}

1) Marshak, A. J. Clin. Invest 28, 1324, 1949

2) Cramer, H.: Z. Krebsforsch, 58, 28, 1951.

3) Cramer, H., H. W. Pabst Z' Krebsforsch, 58, 163. 1952.

4) Low-Beer: Radiol. 39, 573, 1942.

Radiol 47, 213, 1946.

Am. J. Roent. Rad. Ther 67, 28, 1952.

5）森清：新鼬医学誌 68-12, 117, 1954.

\section{Diagnosis of Cancer of Breast and Uterus with Radioactive $\mathrm{P}^{33}$}

\section{Akira TABUCHI Yoshimasa NAKATA Katsuhiko NAKAMURA}

(Depat. of Gyn. Hiroshima Medidical College)

Recently we have made experiment using $\mathrm{P}^{32}$ to diagnose cancer of breast and uterus. This paper is the preliminary report of the sreults obtained by the present time.

$\mathrm{P}^{32}$, radioactive sodium phosphate secondum, is dissolved in $20 \%$ glucose solution an-1 
injected into the cubital vein, the amount of tracer in solution being form 4 to $8 \mu \mathrm{c}$.

The SC-100 A type counter of Kobe Kogyo, Inc. to the breast cancer and the same type equipped with injectional needle type G. M. tube to uterus cancer are used to measre the c. m. p.

In breas cancer, the $c^{\cdot} \mathrm{m}$. p. of cancer lesion increases $32-225 \%$ in comparison with the healthy side, but there is not much difference bteween the c. m. p. of mastopathia and that of normal breast. On the other hand, the c. $m$. p. of cancer lesion in uterus increases $60-220 \%$ in comparison with the normal side, but in simple erosion of cervix, the c. m. p. does not show much increase from that of normal lesion.

Considering from the above result the diagnosis of cancer seems possible by measure of the c. m. p. of P-32 at the deseased lesion. 